\title{
CAUSALITY BETWEEN PUBLIC INVESTMENT IN TRANSPORT AND COMMUNICATION AND ECONOMIC GROWTH
}

\author{
Niloy BosE ${ }^{*}$ AND M. EMRANUl HaQUE \\ University of Wisconsin-Milwaukee and University of Nottingham
}

\begin{abstract}
This paper aims to provide an explanation for the robust and consistent relationship between public investment in transport and communication and economic growth that has frequently surfaced in recent empirical studies. Using both informal and formal causality tests, the paper finds that, for a set of developing countries, the strong association is the result of the effect running from growth to public investment rather than vice versa.
\end{abstract}

Keywords: Transport and Communication Investment, Economic Growth, Causality JEL classification: O42, E62

\section{INTRODUCTION}

Recent externality based growth models suggest that differences in public spending policies are able to explain, at least in part, the observed differences in growth rates across countries. This view has revived interest among economists in re-evaluating the relationship between the levels and the compositions of public spending and growth performances of countries. There does seem to be some pattern emerging from the studies, which have included disaggregated public investment variables within growth regressions. Where significant coefficients have been estimated these are usually confined to public investment expenditure in the transport and communication $(\mathrm{T} \& \mathrm{C})$ sector. For example, Aschauer (1989) finds that public investment in the transport sector is highly correlated with private sector productivity in the United States for the period 1949-85. In a cross-country study, Easterly and Rebelo (1993) find that public investment in $\mathrm{T} \& \mathrm{C}$ sector is consistently positively correlated with growth with a very high coefficient (between 0.59 and 0.66 ). Yet, this association alone does not indicate the direction of causality. For example, one is able to come up with two equally

\footnotetext{
* Corresponding Author. We wish to thank World Bank for allowing us to use their archive at Washington D.C. This work has greatly benefited from the comments and suggestions provided by an anonymous referee on an earlier draft.
} 
plausible hypotheses to account for such an association: (1) public investments in T\&C sector lead growth and the correlation between the two is the result of the effects running from public investment in T\&C sector to growth; and (2) public investments in T\&C sector follow growth, so that rapid growth leads to higher investments in this sector. Clearly, from the policy perspective, there is a need to examine which of the above two hypotheses is more plausible - an issue that has so far eluded the attention of most researchers. ${ }^{1}$ The objective of this paper is to examine this causality issue for a group of developing countries by using a formal method of studying the direction of causation.

\section{DATA}

Existing studies aiming at evaluating growth effects of public investment at a disaggregated level largely suffer from 'sparseness of data' problem. ${ }^{2}$ For us, however, this problem poses a greater challenge. A formal test for causality requires use of leads and lags of the variables in question. Accordingly, such analysis needs to be based on data sets containing relatively large number of observations per country. To overcome this problem, we collected 1970-89 data on central government investment expenditure in the $\mathrm{T} \& \mathrm{C}$ sector for 32 developing countries ${ }^{3}$ by consulting a large collection of World Bank Country Economic Reports and Public Expenditure Reviews. ${ }^{4}$

\section{THE CAUSALITY}

In conducting the analysis, we closely follow the footstep of Blomstrom, et al. (1996) where Granger-Causality argument has been used as a formal way of studying the direction of causation between fixed investment and economic growth. More recently, Attanasio, et al. (2000) adopted the same methodology in analysing the direction of causation between savings, investment, and growth rate.

We begin our preliminary investigation by running simple regressions (see Table 1) of growth rates in per capita GDP on government investment in the T\&C sector in the preceding, current, and the succeeding periods.

\footnotetext{
${ }^{1}$ To our knowledge, the only exception is the study by Easterly and Rebelo (1993) suggesting that effect of public investment in $\mathrm{T} \& \mathrm{C}$ sector on growth is robustly significant with instrumental variable, but the size of the coefficient is disturbingly high - a result which naturally casts doubt on the validity of the procedure and led authors to express the need for further work on this issue.

${ }^{2}$ Due to shortage of data, Easterly and Rebelo (1993) have based their analysis on the decade averages implying only two data points per country.

${ }^{3}$ Please refer to the data appendix for the country list.

${ }^{4}$ Our data set is available upon request.
} 
Table 1. Regressions of Growth rates in Real GDP per capita on T\&C Investment (as a ratio of GDP)

\begin{tabular}{l|l|l|l}
\hline & Preceding period & Current period & Following period \\
\hline Coefficient & 0.29 & 0.39 & 0.47 \\
t-statistic & 1.54 & 2.05 & 2.59 \\
adj $\mathrm{R}^{2}$ & 0.005 & 0.01 & 0.02 \\
No. of obs. & 494 & 510 & 486 \\
\hline
\end{tabular}

Note: t-statistics are White's (1981) heteroschedastic error corrected.

The results above indicate that the coefficients, t-statistics, and adjusted $\mathrm{R}^{2}$ 's increase as one moves from the preceding to the current period and then from there to the succeeding period. Further, to avoid business cycle fluctuations and to acknowledge the possibility of a lagged relationship between public investments in the T\&C sector and growth performances, we regress four-year average growth rates in per capita GDP on preceding, current, and succeeding four-year average government investment in the T\&C sector (Table 2).

Table 2. Regressions of Average Growth rates in Real GDP per capita on Average $\mathrm{T} \& \mathrm{C}$ Investment (as a ratio of GDP)

\begin{tabular}{l|l|l|l}
\hline & Preceding period & Current period & Following period \\
\hline Coefficient & 0.34 & 0.45 & 0.71 \\
t-statistic & 1.29 & 2.12 & 3.06 \\
adj $\mathrm{R}^{2}$ & 0.01 & 0.03 & 0.07 \\
No. of obs. & 113 & 140 & 115 \\
\hline
\end{tabular}

Note: Growth in Real GDP per capita 1970-73, 1974-77, 1978-81, 1982-85 1986-89 (4-year average); Transport and Communication Investemnt (\% of GDP) 1970-73, 1974-77, 1978-81, 1982-85 1986-89 (4-year average); t-statistics are White's (1981) heteroschedastic error corrected.

As in the previous case, results suggest that in the case of the T\&C sector, the effects running from growth to subsequent public investment are stronger than the effects running from public investment to subsequent growth.

For the formal part of our analysis, we turn to the Granger-Sims causality framework (see Granger (1969); Sims (1972)) and employ the block Granger non-causality tests on 20-years of panel data. Making use of the Akaike Information Criterion (AIC) to choose appropriate number of lags (two periods), we follow the above framework to find the direction of causality between the growth rates in per capita real GDP (GY) and public investment in T\&C sector as a percentage of GDP (TCI). The results of the analysis are presented below (t-values are in parentheses): 


$$
\begin{aligned}
G Y_{t} & =0.01+0.29 G Y_{t-1}+0.03 G Y_{t-2}+0.19 T C I_{t-1}-0.04 T C I_{t-2}, \\
& (2.17)(6.06) \quad(0.78) \quad(0.65)
\end{aligned}
$$

adj. $R^{2}=0.09, n=453, \quad \mathrm{p}$-value for joint significance of the coefficients of lags of $T C I=0.62$

$$
\begin{aligned}
T C I_{t}= & 0.002+0.79 T C I_{t-1}+0.08 T C I_{t-2}+0.01 G Y_{t-1}+0.02 G Y_{t-2} . \\
& \text { (2.80) (14.80) }
\end{aligned}
$$

adj. $R^{2}=0.69, n=430, \quad \mathrm{p}$-value for joint significance of the coefficients of lags of $G Y=0.03$

The above results indicate that growth of GDP Granger causes public investment in $\mathrm{T} \& \mathrm{C}$ sector, but there is no evidence of any reverse causality. Robustness of our result is preserved when we repeat the same exercise with country dummies to account for cross-sectional differences among countries. The results ${ }^{5}$ with country dummy variables are presented below:

$$
\begin{gathered}
G Y_{t}=\ldots+0.17 G Y_{t-1}-0.08 G Y_{t-2}-0.001 T C I_{t-1}-0.33 T C I_{t-2}, \\
(3.55) \quad(-1.62) \quad(-0.00) \quad(-1.18)
\end{gathered}
$$

adj. $R^{2}=0.14, n=453, \quad$-value for joint significance of the coefficients of lags of $T C I=0.34$

$$
\begin{aligned}
T C I_{t}=\ldots & +0.52 T C I_{t-1}+0.04 T C I_{t-2}+0.01 G Y_{t-1}+0.02 G Y_{t-2} . \\
(9.75) & (0.84)
\end{aligned}
$$

adj. $R^{2}=0.74, n=430, \quad$-value for joint significance of the coefficients of lags of $G Y=0.10$

The above results indicate that growth of GDP Granger causes public investment in $\mathrm{T} \& \mathrm{C}$ sector, but there is no evidence of any reverse causality. To ensure the robustness further, we next consider an alternative specification recommended in the literature for testing causality. An alternative approach suggested by Sims (1972) considers a linear projection of $y_{t}$ on past, present, and future $x^{\prime} s$ as

$$
y_{t}=a+\sum_{j=0}^{\infty} b_{j} x_{t-j}+\sum_{j=1}^{\infty} d_{j} x_{t+j}+\eta_{t} .
$$

Here $y$ fails to Granger-cause $x$ if and only if $d_{j}=0$ for $j=1,2, \ldots$. However, in implementing this procedure, it is important to take account of any serial correlation in the disturbance term, since otherwise the results of the $F$-test could be misleading. In order to eliminate the serial correlation in the disturbances term, Geweke et al. (1983)

\footnotetext{
${ }^{5}$ Following the usual practice, we have abstained from reporting the coefficients of the dummy variables in $(i)^{\prime}-(v i)^{\prime}$.
} 
suggests incorporating the lagged values of the dependent variable in the regression. ${ }^{6}$ To see the underlying logic, consider that $\eta_{t}$ is in general autocorrelated and $\eta_{t}$ has Wold representation: $\eta_{t}=\Psi(L) v_{t}$, where $\Psi(L)$ is a polynomial in lag operator and $v_{t}$ is a white noise. Multiplying both sides of $(1)$ by $h(L)=[\Psi(L)]^{-1}$ produces

$$
y_{t}=a^{*}-\sum_{j=1}^{\infty} h_{j} y_{t-j}+\sum_{j=0}^{\infty} b_{j}^{*} x_{t-j}+\sum_{j=1}^{\infty} d_{j}^{*} x_{t+j}+v_{t} .
$$

Since, $d_{j}^{*}=0$ for all $j$ if and only if $d_{j}=0$ for all $j$, it is possible to truncate the infinite sums in (2) at some finite value and one can test the null hypothesis that $y$ does not Granger-cause $x$ with an $F$ test of $d_{1}^{*}=d_{2}^{*}=\ldots=d_{p}^{*}=0$. We repeat this procedure with our data and the regression results for without and for with country dummy variables are listed in (iii) and (iii)', respectively.

$$
\begin{gathered}
G Y_{t}=0.00+0.25 G Y_{t-1}+0.005 G Y_{t-2}-0.08 T C I_{t-1}-0.19 T C I_{t-2} \\
(0.71)(4.80) \quad(0.10) \quad(-0.19) \quad(-0.53) \\
+0.16 T C I_{t}-0.02 T C I_{t+1}+0.66_{t+2} \\
(0.40) \quad(-0.05)
\end{gathered}
$$

adj. $R^{2}=0.11, n=354, \quad \mathrm{p}$-value for joint significance of the coefficients of preceding lags of $T C I=0.72 \mathrm{p}$-value for joint significance of the coefficients of following lags of $T C I=0.02$

$$
\begin{gathered}
G Y_{t}=\ldots+0.15 G Y_{t-1}-0.09 G Y_{t-2}-0.003 T C I_{t-1}-0.13 T C I_{t-2} \\
(2.76) \quad(-1.73) \quad(-0.01) \quad(-0.40) \\
-0.08 T C I_{t}+0.16 T C I_{t+1}+0.63 T C I_{t+2} . \\
(-0.23) \quad(0.43)
\end{gathered}
$$

adj. $\quad R^{2}=0.14, n=354, \quad$-value for joint significance of the coefficients of preceding lags of $T C I=0.90 \mathrm{p}$-value for joint significance of the coefficients of following lags of $T C I=0.05$

As before, the results suggest that the widely reported correlation between the investment in the T\&C sector and growth more likely flows from the fact that $\mathrm{T} \& \mathrm{C}$ investments follow growth and not vice-versa.

\footnotetext{
${ }^{6}$ For further details please refer to See Hamilton (1994).
} 
Table 3. Augmented Dicky-Fuller Test for TCI

\begin{tabular}{|c|c|c|c|c|}
\hline & \multicolumn{2}{|c|}{ Levels } & \multicolumn{2}{|c|}{ First Difference } \\
\hline Country & Test statistic & $\begin{array}{c}\text { Critical value } \\
\text { at } 5 \% \text { level }\end{array}$ & Test statistic & $\begin{array}{c}\text { Critical value } \\
\text { at } 5 \% \text { level }\end{array}$ \\
\hline Bahamas & $-1.38(3)$ & -3.07 & $-4.64 * *(2)$ & -3.07 \\
\hline Bangladesh & $-2.36(2)$ & -3.93 & $-3.39 *(1)$ & -3.18 \\
\hline Congo & $-3.13 *(3)$ & -3.12 & - & - \\
\hline Ethiopia & $-2.02(1)$ & -3.69 & $-4.37 *(2)$ & -3.93 \\
\hline Ghana & $-0.77(2)$ & -3.87 & $-3.97 *(2)$ & -3.93 \\
\hline Guatemala & $-2.62(2)$ & -3.05 & $-3.34 *(0)$ & -3.04 \\
\hline Indonesia & $-3.76 *(4)$ & -3.08 & - & - \\
\hline Jamaica & $-1.50(1)$ & -3.05 & $-2.89(0)$ & -3.05 \\
\hline Kenya & $-3.89 *(0)$ & -3.67 & - & - \\
\hline Malawi & $-2.17(3)$ & -3.15 & $-6.01 * *(0)$ & -3.11 \\
\hline Malaysia & $-2.03(1)$ & -3.07 & $-3.59 *(1)$ & -3.08 \\
\hline Morocco & $-1.82(3)$ & -3.76 & $-4.79 * *(1)$ & -3.73 \\
\hline Nepal & $-3.37 *(3)$ & -3.07 & - & - \\
\hline Pakistan & $-3.79 *(3)$ & -3.79 & - & - \\
\hline Sierra Leone & $-3.54(4)$ & -3.76 & $-3.45 *(4)$ & -3.11 \\
\hline SriLanka & $-8.87 * *(4)$ & -3.76 & - & - \\
\hline Sudan & $-3.01(3)$ & -3.87 & $-3.78(0)$ & -3.79 \\
\hline Syria & $-5.59 * *(4)$ & -3.83 & - & - \\
\hline Tanzania & $-3.70(4)$ & -3.76 & $-3.27 *(4)$ & -3.11 \\
\hline Thailand & $-3.13 *(2)$ & -3.07 & - & - \\
\hline
\end{tabular}

Notes: Lags in parentheses are determined using the Akaike Information Criterion (AIC). We have not conducted ADF test for the first difference of TCI if we find its level having no unit root.

* significant at $5 \%$ level; ** significant at $1 \%$ level.

The previous results suggest that, even though past history of public investments in $\mathrm{T} \& \mathrm{C}$ sector explains its current level well, past growth performances improve the prediction. However, high coefficient values of the lags of TCI do raise suspicion regarding the presence of unit roots in the T\&C investment data. In Table 3, we present results of the Augmented Dickey-Fuller (ADF) test for levels and first differences for 20 countries (for which sufficient data points are available to carry out such test). Since the number of observations varies across the countries, we have chosen to report the corresponding critical value of the test statistic for each country.

Table 3 indicates that the data for more than half of the countries contain a unit root. We take the first difference of T\&C investment data $(D T C I)$ in order to make the data 
stationary, ${ }^{7}$ and repeat the same exercise as in $(i)-(i i i)$ and in $(i)^{\prime}-(i i i)^{\prime}$. The corresponding regression results for without and for with country dummies are listed in $(i v)-(v i)$ and in $(i v)^{\prime}-(v i)^{\prime}$, respectively.

$$
\begin{aligned}
G Y_{t}= & 0.01+0.26 G Y_{t-1}+0.06 G Y_{t-2}+0.11 D T C I_{t-1}-0.09 D T C I_{t-2}, \\
& (3.43)(5.40) \quad(1.27) \quad(0.37) \quad(-0.29)
\end{aligned}
$$

adj. $R^{2}=0.08, n=415, \mathrm{p}$-value for joint significance of the coefficients of lags of $T C I=0.86$

$$
\begin{aligned}
D T C I_{t}= & 0.00-0.16 D T C I_{t-1}-0.17 D T C I_{t-2}+0.004 G Y_{t-1}+0.02 G Y_{t-2}, \\
& (0.16)(-2.89) \quad(-3.01)
\end{aligned}
$$

adj. $R^{2}=0.032, n=393, \mathrm{p}$-value for joint significance of the coefficients of lags of $T C I=0.10$

$$
\begin{aligned}
& G Y_{t}=0.01+0.24 G Y_{t-1}+0.04 G Y_{t-2}+0.40 D T C I_{t-1}+0.15 D T C I_{t-2} \\
& \text { (3.27) (4.31) (0.38) (1.08) (0.37) } \\
& +0.72 D^{D T C I_{t}}+0.66 D T C I_{t+1}+0.60 D T C I_{t+2} \text {, } \\
& \text { (1.93) (1.92) (1.95) }
\end{aligned}
$$

adj. $R^{2}=0.08, n=321$, p-value for joint significance of the coefficients of preceding lags of $D T C I=0.55 \mathrm{p}$-value for joint significance of the coefficients of following lags of $D T C I=0.05$

$$
\begin{aligned}
G Y_{t}=\ldots+ & 0.15 G Y_{t-1}-0.06 G Y_{t-2}+0.18 D T C I_{t-1}+0.07 D T C I_{t-2}, \\
& (2.92) \quad(-1.17) \quad(0.65)
\end{aligned}
$$

adj. $R^{2}=0.12, n=415, \quad \mathrm{p}$-value for joint significance of the coefficients of lags of $T C I=0.81$

$$
\begin{aligned}
D T C I_{t}= & \ldots-0.27 D T C I_{t-1}-0.21 D T C I_{t-2}+0.01 G Y_{t-1}+0.015 G Y_{t-2}, \\
& (-4.82) \quad(-3.54)
\end{aligned}
$$

adj. $R^{2}=0.03, n=393, \mathrm{p}$-value for joint significance of the coefficients of lags of $G Y=0.14$

$$
\begin{aligned}
& G Y_{t}=\ldots+0.12 G Y_{t-1}-0.06 G Y_{t-2}+0.23 D T C I_{t-1}+0.07 D T C I_{t-2} \\
& \begin{array}{llll}
(2.04) & (-1.13) \quad(0.62) \quad(0.18)
\end{array} \\
& +0.53 D^{2} C I_{t}+0.62 D T C I_{t+1}+0.55 D T C I_{t+2} \text {. } \\
& \text { (1.43) (1.88) (1.84) }
\end{aligned}
$$

adj. $\quad R^{2}=0.13, n=321, \quad \mathrm{p}$-value for joint significance of the coefficients of preceding lags of

${ }^{7}$ Our dependent variable, the growth rate of GDP per capita $(G Y)$, is generally accepted to be an $\mathrm{I}(0)$ variable. Accordingly, the need for any cointegration analysis does not arise when we use the first difference of the right hand side variable (TCI). 
$D T C I=0.82 \mathrm{p}$-value for joint significance of the coefficients of following lags of $D T C I=0.07$

Although the inclusion of the country dummy variables makes the Granger-causality results relatively less robust, the Sims-Geweke causality result holds and overall, results are supportive of the hypothesis that the direction of causality is from growth to public investments in the T\&C sector and not vice versa. To obtain further insight, we extend our analysis to explore the causal relationship between growth and transport and communication investment per- capita (TCIPC). Operationally we run regressions (i) $-(v i)$ and $(i)^{\prime}-(v i)^{\prime}$ after substituting TCI by TCIPC. To economize on space, we abstain from reporting the whole regression results and report the p-values of the regressions in Table 4 below. As the results indicate, even a stronger support for our hypothesis is obtained in this case.

Table 4. Causality Between Growth Rates in Real GDP per Capita on T\&C Investment per Capita (TCIPC)

\begin{tabular}{|c|c|c|c|c|}
\hline & $\begin{array}{c}\text { Causality } \\
\text { Test }\end{array}$ & $\begin{array}{l}\text { p-value for joint } \\
\text { significance of } \\
\text { preceding lags of } \\
\text { TCIPC on GY }\end{array}$ & $\begin{array}{l}\text { p-value for joint } \\
\text { significance of } \\
\text { preceding lags of } \\
\text { GY on TCIPC }\end{array}$ & $\begin{array}{l}\text { p-value for joint } \\
\text { significance of } \\
\text { following lags of } \\
\text { TCIPC on GY }\end{array}$ \\
\hline Causation $\rightarrow$ & & TCIPC $\rightarrow$ GY & GY $\rightarrow$ TCIPC & GY $\rightarrow$ TCIPC \\
\hline \multicolumn{5}{|c|}{ Without country dummies } \\
\hline Regression (i) & Granger & 0.43 & -- & -- \\
\hline Regression (ii) & Granger & -- & 0.02 & -- \\
\hline Regression (iii) & Sims-Geweke & 0.50 & -- & 0.00 \\
\hline Regression (iv) & Granger & 0.73 & -- & -- \\
\hline Regression (v) & Granger & -- & 0.04 & -- \\
\hline Regression (vi) & Sims-Geweke & 0.24 & -- & 0.00 \\
\hline \multicolumn{5}{|c|}{ With country dummies } \\
\hline Regression $(i)^{\prime}$ & Granger & 0.25 & -- & -- \\
\hline Regression (ii)' & Granger & -- & 0.03 & -- \\
\hline Regression (iii)' & Sims-Geweke & 0.64 & -- & 0.00 \\
\hline Regression (iv)' & Granger & 0.76 & -- & -- \\
\hline Regression $(v)^{\prime}$ & Granger & -- & 0.00 & -- \\
\hline Regression $(v i)^{\prime}$ & Sims-Geweke & 0.47 & -- & 0.00 \\
\hline
\end{tabular}

$*$ TCIPC $=$ T\&C Investment (in million local currency units) per capita.

\section{CONCLUDING REMARKS}

It is commonly believed that public investment in infrastructure is important for a country's economic performance. Such believe has been validated on the basis of both 
country-specific studies (e.g., Rioja (2001); Mamatzakis (2002)) and cross-country studies (e.g., Cashin (1995); Fuente (1997); Kneller et al. (1999)). In this paper we investigate this association at a much disaggregated level. In particular, the objective of this study has been to evaluate the direction of causality between the public investment in the transport and communication sector and economic growth for a set of developing countries. Our analysis suggests that the widely reported association between the two variables are more due to growth causing investment in the transport and communication sector and not vice-versa. While such conclusion has been drawn on the basis of well-established procedures, there exists room for improvements in our analysis. The studies by Frankel (1962), Griliches (1979), Romer (1986) and Lucas(1988) have established a strong viewpoint that in evaluating the impact of investment on growth, one should pay attention to externality effects arising from both "learning by doing" and "technology spill-over" effects. This is particularly true in the case of transport and communication investments due to its non-rival characteristics. Although, by definition, public investments (in T\&C sector) capture some of this characteristics, we acknowledge the necessity for including an additional variable in the regression that reflects the total volume of non-rival ideas in this sector. Aggregate capital stock in the transport and communication sector is a natural choice for such variable. However, lack of data has prevented us to include this variable in the analysis. Finally, data used in this paper are hand-collected for the period 1970-89 to obtain an overlap of the period of analysis with other existing studies (e.g., Aschauer (1989); Easterly and Rebelo (1993)) which report strong association between the two variables. We, however, acknowledge the need to extend the analysis with a more current data set. This remains as a part of our future research agenda.

\section{REFERENCES}

Aschauer, D.A. (1989), "Is Government Spending Productive?" Journal of Monetary Economics, 23, 177-200.

Attanasio, O.P., L. Picci, and, A.E. Scorcu (2000), "Saving, Growth, and Investment: A Macroeconomic Analysis Using a Panel of Countries," The Review of Economics and Statistics, Vol. 82, Number 2, 182-211.

Blomstrom, M., R.E. Lipsey, and M. Zejan (1996), "Is Fixed Investment Key to Economic Growth," Quarterly Journal of Economics, Vol. 111, Issue 1 (February), 269-276.

Cashin, P. (1995), "Government Spending, Taxes, and Economic Growth," IMF Staff Papers, Vol. 42, No. 2 (June), 237-269.

Easterly, W., and S. Rebelo (1993), "Fiscal Policy and Economic Growth: An Empirical Investigation," Journal of Monetary Economics, 32 (December), 417-458. 
Fuente, de la A. (1997), "Fiscal Policy and Growth in OECD," CEPR Discussion Paper, 1755.

Frankel, M. (1962), "The production Function in Allocation and Growth: A synthesis," American Economic Review, 52, December, 995-1022.

Geweke, J., R. Meese, and W. Dent (1983), "Comparing Alternative Tests of Causality in Temporal Systems," Journal of Econometrics, 21, 161-194.

Granger, C.W.J. (1969), "Investigating Causal Relations by Econometric Models and Cross-Spectral Methods," Econometrica, 37 (July), 424-38.

Griliches, Z. (1979), "Issues in Assessing the Contribution of Research and Development to Productivity Growth," Bell Journal of Economics, 10(1), 92-116.

Hamilton, J.D. (1994), “Time Series Analysis" Princeton University Press.

Kneller, R., M.F. Bleany, and N. Gemmell (1999), "Fiscal Policy and Growth: Evidence from OECD Countries," Journal of Public Economics, Vol. 74, 171-190.

Lucas, R.E. (1988). "On the Mechanics of Economic Development," Journal of Monetary Economics, 22, July, 3-42.

Mamatzakis, E.C. (2002), "Public Infrastructure and Private Output: An Application to Greece," Journal of Economic Development, Volume 27, Number 2, December, 143-160.

Rioja, F.K. (2001), "Growth, Welfare, and Public Infrastructure: A General Equilibrium Analysis of Latin American Economies," Journal of Economic Development, Volume 26, Number 2, December, 119-130.

Romer, P.M. (1986), "Increasing Returns and Long-Run Growth," Journal of Political Economy, 94, October, 1002-1037.

Sims, C.A. (1972), "Money, Income and Causality," American Economic Review, 62, 4 (September), 540-52.

Mailing Address: Niloy Bose: The Department of Economics University of Wisconsin-Milwaukee WI 53201,USA.E-mail:nbose@uwm.edu

M. Emranul Haque: Leverhulme Centre for Globalisation and Economic Policy School of Economics University of Nottingham NG9 2RD, England.E-mail: m.haque@nottingham.ac.uk 


\section{DATA APPENDIX}

Table A1. Growth Rate in GDP per Capita

\begin{tabular}{l|c|r|r|r|r|r|r}
\hline & Obs & \multicolumn{1}{c|}{ Mean } & Std. Dev. & \multicolumn{1}{l}{ Min } & Max & $\mathbf{1 9 7 0}$ & $\mathbf{1 9 8 9}$ \\
\hline BAHAMAS & 19 & .0112105 & .0998736 & -.189 & .237 & -- & -.018 \\
BANGLADESH & 20 & .00635 & .0508209 & -.139 & .106 & .034 & .003 \\
BHUTAN & 20 & .01585 & .0505967 & -.023 & .171 & -.013 & .004 \\
BOTSWANA & 20 & .0934 & .0765557 & -.05 & .283 & .006 & .095 \\
BURUNDI & 20 & .0437 & .1130543 & -.077 & .439 & .206 & -.013 \\
CHINA & 17 & .0624706 & .0484692 & -.069 & .131 & -- & .027 \\
CONGO & 20 & .0364 & .082866 & -.136 & .231 & .036 & -.006 \\
ETHIOPIA & 20 & -.0005 & .0357189 & -.095 & .063 & .039 & -.019 \\
GHANA & 20 & -.0093 & .059405 & -.156 & .084 & .066 & .017 \\
GUATEMALA & 20 & .0059 & .0337544 & -.063 & .050 & .029 & .010 \\
INDONESIA & 20 & .0434 & .0211222 & -.022 & .070 & .050 & .056 \\
JAMAICA & 20 & -.0025 & .0518312 & -.082 & .105 & .105 & .060 \\
KENYA & 20 & .0204 & .0594894 & -.082 & .190 & -.082 & .013 \\
MALAWI & 20 & .00805 & .0446654 & -.083 & .135 & -.025 & -.029 \\
MADAGASCAR & 20 & -.01745 & .0401451 & -.125 & .072 & .030 & .009 \\
MALAYSIA & 20 & .0433 & .03421 & -.037 & .095 & .035 & .068 \\
MOROCCO & 20 & .0224 & .0383741 & -.054 & .084 & .025 & -.003 \\
MAURTIOUS & 20 & .02975 & .0521333 & -.128 & .109 & -.030 & .020 \\
MOZAMBIQUE & 20 & -.0545 & .0693424 & -.188 & .031 & -.023 & .015 \\
NEPAL & 20 & .00375 & .0340354 & -.062 & .066 & -.002 & .014 \\
NIGERIA & 20 & .00615 & .0727478 & -.122 & .161 & .161 & .036 \\
PAKISTAN & 20 & .02675 & .0281852 & -.029 & .079 & .079 & .018 \\
RWANDA & 20 & .0147 & .0535322 & -.055 & .166 & .031 & -.036 \\
SRLANKA & 20 & .01535 & .0252467 & -.052 & .066 & .001 & -.006 \\
SIERRA LEONE & 20 & .00545 & .0461958 & -.071 & .098 & .098 & .014 \\
SUDAN & 20 & -.00225 & .0804356 & -.135 & .152 & .013 & .041 \\
SYRIA & 20 & .02805 & .0966325 & -.136 & .205 & -.053 & -.136 \\
THAILAND & 20 & .05005 & .0305122 & .023 & .116 & .080 & .104 \\
TANZANIA & 20 & .01195 & .0282013 & -.032 & .066 & .039 & .066 \\
TUNISIA & 20 & .02335 & .0444963 & -.047 & .148 & .017 & -.015 \\
ZAIRE & 20 & -.01905 & .0385602 & -.087 & .058 & .006 & -.050 \\
ZAMBIA & 20 & .0147 & .0390844 & -.047 & .103 & .027 & -.009 \\
\hline
\end{tabular}


Table A2. Public Investment in Transport and Communication as a Ratio of GDP

\begin{tabular}{|c|c|c|c|c|c|c|c|}
\hline & Obs & Mean & Std. Dev. & Min & Max & 1970 & 1989 \\
\hline BAHAMAS & 20 & .0039500 & .0027237 & .001 & .010 & .004 & .002 \\
\hline BANGLADESH & 14 & 0154286 & .0041457 & .008 & .023 & -- & .014 \\
\hline BHUTAN & 10 & .0579000 & 0386881 & .020 & .151 & -- & .151 \\
\hline BOTSWANA & 9 & 0307778 & .0081052 & .024 & .050 & -- & -- \\
\hline BURUNDI & 8 & .0278750 & .0132065 & .018 & .057 & -- & -- \\
\hline CHINA & 6 & 0091667 & .0027142 & .005 & .012 & -- & .005 \\
\hline CONGO & 17 & .0467647 & .0294714 & 0 & .097 & 0 & - \\
\hline ETHIOPIA & 20 & .0163500 & .0067922 & .008 & .038 & .008 & .038 \\
\hline GHANA & 15 & .0017333 & .0016242 & 0 & .005 & -- & .005 \\
\hline GUATEMALA & 20 & .0069500 & .0030689 & .003 & .015 & .007 & .005 \\
\hline INDONESIA & 20 & .0114000 & .0045468 & .005 & .020 & .007 & .010 \\
\hline JAMAICA & 17 & 0132941 & .0080759 & .003 & .028 & .008 & -- \\
\hline KENYA & 20 & .0008500 & .0003663 & 0 & .001 & .001 & .001 \\
\hline MALAWI & 16 & 0368750 & .0182204 & .016 & .072 & .028 & -- \\
\hline MADAGASCAR & 14 & 0165714 & .0084098 & .006 & .034 & 017 & .029 \\
\hline MALAYSIA & 18 & 0222222 & .0074720 & 010 & 038 & .010 & - \\
\hline MOROCCO & 19 & .0251053 & 0097576 & 012 & 043 & & .016 \\
\hline MAURTIOUS & 14 & .0065000 & .0041091 & .001 & .015 & .001 & - \\
\hline MOZAMBIQUE & 7 & .0060000 & .0034641 & .002 & .013 & -- & -- \\
\hline NEPAL & 20 & .0239500 & .0033003 & .016 & .029 & .026 & .029 \\
\hline NIGERIA & 18 & .0213889 & 0166985 & .001 & .054 & .001 & .005 \\
\hline PAKISTAN & 18 & 0140556 & .0040941 & .008 & .021 & .008 & - \\
\hline RWANDA & 17 & .0094118 & 0112364 & .001 & 032 & .001 & -- \\
\hline SRLANKA & 20 & .0203500 & .0092297 & .005 & .042 & .007 & .026 \\
\hline SIERRA LEONE & 20 & .0086000 & .0065083 & 0 & .024 & .020 & .001 \\
\hline SUDAN & 16 & .0085625 & .0060879 & .001 & .021 & .004 & -- \\
\hline SYRIA & 18 & 0367222 & .0072664 & .026 & .051 & 032 & -- \\
\hline THAILAND & 19 & .0120526 & 0030817 & .008 & .018 & 017 & -- \\
\hline TANZANIA & 20 & 0119000 & 0075177 & .004 & .030 & .019 & .006 \\
\hline TUNISIA & 12 & .0107500 & 0022613 & .007 & .014 & .010 & - \\
\hline ZAIRE & 11 & .0020000 & .0033466 & 0 & 012 & .001 & -- \\
\hline ZAMBIA & 18 & 0282778 & .0231715 & .001 & .082 & .046 & .013 \\
\hline
\end{tabular}

